Archives of Agriculture and Environmental Science

\title{
Effects of bio-slurry with chemical fertilizer on the performance of some high yielding varieties of boro rice (Oryza sativa L.)
}

\author{
M.N. Hossain ${ }^{1}$, U.K. Sarker ${ }^{1}$, M.R. Uddin ${ }^{1 *}$ (D) , S. Rehana ${ }^{2}$, M.M.I. Hoque ${ }^{3}$ and M.A. Islam ${ }^{4}$ \\ ${ }^{1}$ Department of Agronomy, Bangladesh Agricultural University, Mymensingh-2202, BANGLADESH \\ ${ }^{2}$ Biotechnology and Genetic Engineering Discipline, Khulna University, Khulna, BANGLADESH \\ ${ }^{3} \mathrm{ACI}$ Limited, Dhaka, BANGLADESH \\ ${ }^{4}$ Bangladesh Agricultural Development Corporation, Kishoreganj, BANGLADESH \\ "Corresponding author's Email: romijagron@bau.edu.bd
}

\section{ARTICLE HISTORY}

Received: 21 May 2018

Accepted: 30 May 2018

\section{Keywords}

Bio-slurry

Crop yield

Effective tillers

Fertilizer management

Harvest index

High yield varieties

\begin{abstract}
Rice yield is greatly influenced by application of manures and fertilizer. Integrated use of organic manure and chemical fertilizer would be quite promising in providing better yield. To evaluate the effect of bio-slurry along with chemical fertilizer, a field experiment was conducted in the Agronomy Field Laboratory, Bangladesh Agricultural University, Mymensingh, Bangladesh. The experiment was comprised of four varieties of boro (dry season irrigated) rice viz., (i) BRRI dhan28, (ii) BRRI dhan29 (iii) Binadhan-8 (iv) Binadhan-10 and four fertilizer management viz., (i) control, (ii) recommended dose of inorganic fertilizer, (iii) bio-slurry@ $5 \mathrm{t}$ $\mathrm{ha}^{-1}+$ inorganic fertilizer, (iv) farmers' practice (average 15 farmers). The experiment was laid out in a randomized complete block design with three replications. It is evident that variety and fertilizer management had significant effect on effective tillers hill ${ }^{-1}$, number of grains panicle ${ }^{-1}$ which ultimately influenced grain yield. The highest grain yield was $\left(6.03 \mathrm{t} \mathrm{ha}^{-1}\right)$ in Binadhan-8 followed by Binadhan-10 and BRRI dhan29. The lowest grain yield was found from BRRI dhan28. In respect of fertilizer management, grain yield was highest $\left(5.90 \mathrm{t} \mathrm{ha}^{-1}\right)$ in bio-slurry @ $5 \mathrm{t} / \mathrm{ha}+$ inorganic fertilizer. The lowest grain yield was found from control. The combined effect of variety and fertilizer application showed that highest grain yield $\left(6.10 \mathrm{t} \mathrm{ha}^{-1}\right)$ was found from Binadhan-8 with bio-slurry @ $5 \mathrm{t} \mathrm{ha}^{-1}+$ inorganic fertilizer and the lowest grain yield (4.68 $\mathrm{t} \mathrm{ha}^{-1}$ ) was found from BRRI dhan28 with farmers' practice. Thus, the variety Binadhan-8 with application of bio-slurry @ $5 \mathrm{t} \mathrm{ha}^{-1}+$ inorganic fertilizer was superior for obtaining highest yield.
\end{abstract}

(C)2018 Agriculture and Environmental Science Academy

Citation of this article: Hossain, M.N., Sarker, U.K., Uddin, M.R., Rehana, S., Hoque, M.M.I. and Islam, M.A. (2018). Effects of bio-slurry with chemical fertilizer on the performance of some high yielding varieties of boro rice (Oryza sativa L.). Archives of Agriculture and Environmental Science, 3(2): 109-115, https://dx.doi.org/10.26832/24566632.2018.030202

\section{INTRODUCTION}

The dependency on agriculture in Bangladesh is gradually increasing, most of the people of Bangladesh earn their living from agriculture directly or indirectly and predominantly rice based, which contributes a lot to our gross domestic product (GDP). In proportion to our population the cultivable land is not enough. Moreover, farmers' of our country are not well aware regarding cultivation of rice varieties (Khan et al., 2015; Islam et al., 2017). Use of local cultivars indiscriminately is one of the most important reasons for low yield. The farmers' of our country are not well aware of selection of potential variety. Moreover, to meet the demand of increasing population farmers are using excessive chemical fertilizers for their crop production which ultimately create hazardous situation to soil. Soil fertility is also declining because of increasing cropping intensity coupled with the minimum use of organic manure (Khan et al., 2015; Cuong et al., 2017). According to an appraisal report of 
Bangladesh soil resources, soils of about $6.10 \mathrm{~m}$ ha contain very low (less than 1\%) organic matter, $2.15 \mathrm{~m}$ ha contain low (1-2\%) organic matter and the remaining $0.90 \mathrm{~m}$ ha contain more than $2 \%$ organic matter (Mondal, 2000). A good soil should have an organic matter content of at least 2.5\% (BARC, 2005). But in Bangladesh, most soils have less than $1.7 \%$, and some soils have even less than $1 \%$ organic matter. The average organic matter content of top soils has declined by $20-46 \%$ over past 20 years due to intensive cropping without inclusion of legume crops, imbalance use of fertilizer, use of modern varieties and scanty use of organic manure (Jeptoo et al., 2013; Dada et al., 2015).

It is agreed that decreases in soil fertility is a major constraint for higher crop production in Bangladesh. The beneficial effect of organic manure in crop production has been demonstrated by many workers (Jeptoo et al., 2013; Asadul et al., 2015). Maintenance of soil fertility is a prerequisite for long term sustainable crop production and it is certain that organic manure (e.g. bioslurry) can play a vital role in the sustainability of soil fertility and crop production (Shankarappa et al., 2012; Khan et al., 2015). Application of by-product of the recently popularized biogas technology named 'bio-slurry'. Bio-slurry is a good source of plant nutrients and can improve soil properties (Garg et al., 2005; Asadul et al., 2015). Gupta (2007) reported that bioslurry contains many rich and nutritive elements including $\mathrm{N}, \mathrm{P}$, $\mathrm{K}$ and trace elements ( $\mathrm{Zn}, \mathrm{Fe}, \mathrm{Cu}, \mathrm{Ni}, \mathrm{Ca}$ etc). Bio-slurry contains appreciable amounts of organic matter (20 to 30\%) very much needed for our hungry soils. Bio-slurry can be utilized as a potential bio-manure in crop production (Khan et al., 2015). It can improve the physical and biological quality of soil by adding organic matter to the soil. It also provides both macro and micro -nutrients such as zinc, iron, manganese and copper that are also essential for plants but required in trace amounts to crops (Jeptoo et al., 2013). These improve in water holding capacity, cation exchange capacity, lesser soil erosion and provision of nutrients to plants and soil micro-flora including $\mathrm{N}$ fixing and phosphorus solubilizing organisms. So bio-slurry can play a vital role in increasing yield as well as to maintain soil health (Shankarappa et al., 2012; Asadul et al., 2015; Khan et al., 2015; Islam et al., 2017). Considering the above mentioned points the experiment was undertaken to evaluate the effects of variety on the yield and yield contributing characters of boro rice, to determine the suitability of different sources of organic and inorganic fertilizer including bio-slurry on yield contributing characters of boro rice and to find interaction of variety and fertilizer management for boro rice yield.

\section{MATERIALS AND METHODS}

\section{Experimental site and design}

The experiments were performed at the Agronomy Field Laboratory of Bangladesh Agricultural University, Mymensingh during the period of November 2015 to June 2016 to study the effect of bio-slurry on the performance of boro rice. The experimental site is located at $24^{\circ} 75^{\prime} \mathrm{N}$ latitude and $90^{\circ} 50^{\prime} \mathrm{E}$ longitude at an elevation of $18 \mathrm{~m}$ above the mean sea level. The experimental area is characterized by non-calcareous dark grey floodplain soil belonging to the Sonatola Soil Series under the Old Brahmaputra Floodplain, Agro-Ecological Zone 9 (FAO and UNDP, 1988). The soil of the experimental field was more or less neutral in reaction with $\mathrm{pH}$ value 6.8, low in organic matter and fertility level. The land type was medium high with silty loam in texture. The experimental treatments consists of four cultivars namely $\mathrm{V}_{1}=\mathrm{BRRI}$ dhan28, $\mathrm{V}_{2}=$ BRRI dhan29, $\mathrm{V}_{3}=$ Binadhan-8 and $V_{4}=$ Binadhan-10 and four fertilizer doses $T_{1}=$ Control (no manure and fertilizer), $T_{2}=$ Recommended dose of inorganic fertilizer (N-P-K-S-Zn@140-60-80-2-10 kg ha-1 ${ }^{-1}, T_{3}=$ Bio-slurry @ 5t/ha + inorganic fertilizer and $T_{4}=$ Farmers' practice (average 15 farmers). The experiment was laid out in a randomized complete block design (RCBD) with three replications. The unit plot size was $4.0 \mathrm{~m} \times 2.5 \mathrm{~m}$. The distance maintained between the individual unit plots was $0.5 \mathrm{~m}$ and that between the replications $1.0 \mathrm{~m}$. The experimental land was first opened with a tractor drawn disc plough. The land was then puddled thoroughly by repeated ploughing and cross ploughing with a country plough and subsequently leveled by laddering. Weeds and stubbles were cleared off from individual plot.

\section{Cultivation practices and fertilizer management}

Fertilizer was applied as per specification based on treatment. Calculation of nutrients on IPNS basis was done and only required amount were applied from fertilizers. Whole amounts of other fertilizers except Urea were applied during the final land preparation. Urea was applied in three equal splits at 15 , 40 and 70 days after transplanting (DAT), respectively. Thirty five day old seedlings of rice were transplanted on the well puddled experimental plots on 24 January 2016. The plot were kept weed free up to 60 days after transplanting by hand weeding as and when needed but afterwards no weeding was done. Irrigation was given to maintain a level of standing water up to 2 $-4 \mathrm{~cm}$ till maximum tillering stage and after that, a water level of 7-10 cm was maintained up to grain filling stage and then drained out of the field after milk stage to enhance maturity.

\section{Observation and data collection}

The experimental crop of each plot was harvested separately at full maturity on 7 May 2016. The grain and straw weights for each plot were recorded after proper sun drying and then converted into ton per hectare. The grain yield was adjusted at $14 \%$ moisture level. Prior to harvesting, five plants were selected randomly from each plot excluding border plants and uprooted carefully for collecting data on yield contributing characters.

\section{Statistical analysis}

All the collected data were analyzed following the Analysis of Variance (ANOVA) technique and mean differences were adjudged by Duncan's Multiple Range Test (DMRT) (Gomez and Gomez, 1984) using a computer operated programme named MSTAT. 
Table 1. Effect of cultivars on plan characters, yield and yield components of boro rice varieties.

\begin{tabular}{lccccccc}
\hline Treatment & $\begin{array}{c}\text { Plant } \\
\text { height } \\
\text { (cm) }\end{array}$ & $\begin{array}{c}\text { No. of } \\
\text { total tillers } \\
\text { hill }^{-1}\end{array}$ & $\begin{array}{c}\text { No. of } \\
\text { effective } \\
\text { tillers hill }\end{array}$ & $\begin{array}{c}\text { Panicle } \\
\text { length } \\
\text { (cm) }\end{array}$ & $\begin{array}{c}\text { No. of grains } \\
\text { panicle }^{-1}\end{array}$ & $\begin{array}{c}\text { 1000-grain } \\
\text { weight (g) }\end{array}$ & $\begin{array}{c}\text { Harvest } \\
\text { index } \\
\text { (\%) }\end{array}$ \\
\hline $\mathrm{V}_{1}$ & 74.17 & $12.09 \mathrm{c}$ & $8.87 \mathrm{c}$ & 19.82 & $73.54 \mathrm{~b}$ & $25.23 \mathrm{~b}$ & $24.35 \mathrm{c}$ \\
$\mathrm{V}_{2}$ & 77.39 & $12.96 \mathrm{~b}$ & $10.27 \mathrm{~b}$ & 19.56 & $83.33 \mathrm{a}$ & $25.85 \mathrm{a}$ & $33.27 \mathrm{~b}$ \\
$\mathrm{~V}_{3}$ & 77.30 & $14.16 \mathrm{a}$ & $13.56 \mathrm{a}$ & 19.90 & $86.86 \mathrm{a}$ & $24.97 \mathrm{~b}$ & $47.25 \mathrm{a}$ \\
$\mathrm{V}_{4}$ & 80.06 & $12.72 \mathrm{~b}$ & $11.76 \mathrm{~b}$ & 20.60 & $85.87 \mathrm{a}$ & $24.74 \mathrm{~b}$ & $45.60 \mathrm{~d}$ \\
Level of significance & $\mathrm{NS}$ & $* *$ & $* *$ & $\mathrm{NS}$ & $* *$ & $* *$ & $* *$ \\
CV (\%) & 3.47 & 2.81 & 4.30 & 3.33 & 1.95 & 1.37 \\
\hline
\end{tabular}

In a column, figures with same letters or without letters do not differ significantly whereas figures with dissimilar letter differ significantly as per DMRT; NS = Non-significant; ${ }^{* *}=$ Significant at $1 \%$ level of probability; $V_{1}=$ BRRI dhan $28, V_{2}=$ BRRI dhan $29, V_{3}=$ Binadhan-8, $V_{4}=$ Binadhan-10.

Table 2. Effect of fertilizer management on plan characters, yield and yield components of boro rice varieties.

\begin{tabular}{|c|c|c|c|c|c|c|c|}
\hline Treatment & $\begin{array}{c}\text { Plant } \\
\text { height } \\
(\mathrm{cm})\end{array}$ & $\begin{array}{c}\begin{array}{c}\text { No. of } \\
\text { total tillers } \\
\text { hill }^{-1}\end{array} \\
\end{array}$ & $\begin{array}{c}\text { No. of } \\
\text { effective } \\
\text { tillers hill }^{-1}\end{array}$ & $\begin{array}{c}\text { Panicle } \\
\text { length } \\
(\mathrm{cm})\end{array}$ & $\begin{array}{l}\text { No. of } \\
\text { grains } \\
\text { panicle }^{-1} \\
\end{array}$ & $\begin{array}{l}\text { 1000- grain } \\
\text { weight (g) }\end{array}$ & $\begin{array}{c}\text { Harvest } \\
\text { index } \\
(\%)\end{array}$ \\
\hline $\mathrm{T}_{1}$ & 75.91 & $12.18 \mathrm{c}$ & $10.14 \mathrm{c}$ & $19.08 b$ & $77.77 c$ & $24.68 b$ & $24.38 d$ \\
\hline $\mathrm{T}_{2}$ & 77.59 & $13.24 a b$ & $11.31 \mathrm{ab}$ & $20.34 a$ & $84.08 \mathrm{a}$ & $25.10 \mathrm{~b}$ & $34.68 \mathrm{c}$ \\
\hline $\mathrm{T}_{3}$ & 79.15 & $13.76 \mathrm{a}$ & $12.03 \mathrm{a}$ & $20.60 a$ & $85.32 \mathrm{a}$ & $25.94 \mathrm{a}$ & $46.75 a$ \\
\hline $\mathrm{T}_{4}$ & 76.29 & $12.75 \mathrm{bc}$ & $11.03 b$ & $19.87 \mathrm{ab}$ & $81.43 b$ & $25.07 \mathrm{~b}$ & $43.25 b$ \\
\hline Level of significance & NS & $* *$ & $* *$ & * & $* *$ & $* *$ & $* *$ \\
\hline CV (\%) & 3.47 & 2.81 & 4.30 & 3.33 & 1.95 & 1.37 & 4.65 \\
\hline
\end{tabular}

In a column, figures with same letters or without letters do not differ significantly whereas figures with dissimilar letter differ significantly as per DMRT; NS = Non-significant; ${ }^{*}=$ Significant at $5 \%$ level of probability; ${ }^{* *}=$ Significant at $1 \%$ level of probability; $\mathrm{T}_{1}=$ Control (no manure \& fertilizer), $\mathrm{T}_{2}=$ Recommended dose of inorganic fertilizer; $\mathrm{T}_{3}=$ Bio-slurry @ $5 \mathrm{t} /$ ha + Inorganic fertilizer, $\mathrm{T}_{4}=$ Farmers' practice (average 15 farmers).

Table 3. Interaction effect of variety and fertilizer management on plan characters, yield and yield components of boro rice varieties.

\begin{tabular}{|c|c|c|c|c|c|c|c|c|c|}
\hline $\begin{array}{l}\text { Cultivars } x \\
\text { treatment }\end{array}$ & $\begin{array}{c}\text { Plant } \\
\text { height } \\
(\mathrm{cm})\end{array}$ & $\begin{array}{l}\text { No. of } \\
\text { total till- } \\
\text { ers hill }^{-1}\end{array}$ & $\begin{array}{c}\text { No. of } \\
\text { effective } \\
\text { tillers } \\
\text { hill }^{-1}\end{array}$ & $\begin{array}{c}\text { Panicle } \\
\text { length } \\
(\mathrm{cm})\end{array}$ & $\begin{array}{l}\text { No. of } \\
\text { grains } \\
\text { panicle }^{-1}\end{array}$ & $\begin{array}{c}\text { 1000- } \\
\text { grain } \\
\text { weight }(\mathrm{g})\end{array}$ & $\begin{array}{l}\text { Grain } \\
\text { yield } \\
\text { (t ha }{ }^{-1)}\end{array}$ & $\begin{array}{c}\text { Straw } \\
\text { yield } \\
\left(\mathrm{t} \mathrm{ha}^{-1}\right)\end{array}$ & $\begin{array}{c}\text { Harvest } \\
\text { index } \\
(\%)\end{array}$ \\
\hline$V_{1} T_{1}$ & $72.93 e$ & $10.87 \mathrm{~h}$ & $7.80 \mathrm{j}$ & $18.40 \mathrm{~g}$ & $70.84 h$ & 25.10def & $4.76 \mathrm{~g}$ & $4.75 \mathrm{k}$ & $29.40 f$ \\
\hline$V_{1} T_{2}$ & 73.73de & $12.50 \mathrm{ef}$ & $8.43 \mathrm{ij}$ & $20.50 a b c$ & $74.05 \mathrm{fg}$ & 25.03efg & $4.93 f$ & $5.25 \mathrm{j}$ & $30.10 f$ \\
\hline$V_{1} T_{3}$ & $77.90 b c$ & $12.97 \mathrm{de}$ & $9.87 f g$ & 21.28a & $75.87 f$ & $25.80 b c$ & 4.83ge & $6.00 \mathrm{~h}$ & $33.50 \mathrm{e}$ \\
\hline $\mathrm{V}_{1} \mathrm{~T}_{4}$ & $72.13 \mathrm{e}$ & 12.00fg & 9.37gh & 19.10efg & $73.40 \mathrm{~g}$ & 24.97efg & $4.68 \mathrm{~g}$ & $5.35 \mathrm{ij}$ & $34.81 \mathrm{e}$ \\
\hline $\mathrm{V}_{2} \mathrm{~T}_{1}$ & $72.83 e$ & $11.93 \mathrm{~g}$ & 8.90hi & $18.90 \mathrm{fg}$ & $79.43 e$ & $25.50 \mathrm{~cd}$ & $5.03 f$ & $5.40 \mathrm{i}$ & 30.30 ef \\
\hline $\mathrm{V}_{2} \mathrm{~T}_{2}$ & $78.20 \mathrm{~b}$ & $13.27 \mathrm{~cd}$ & $10.67 \mathrm{de}$ & $19.48 \mathrm{def}$ & $83.97 c$ & $26.03 a b$ & $5.83 d$ & $6.00 \mathrm{~h}$ & $33.20 \mathrm{e}$ \\
\hline $\mathrm{V}_{2} \mathrm{~T}_{3}$ & $79.40 \mathrm{~b}$ & $13.70 b c$ & $11.37 d$ & $19.93 \mathrm{bcde}$ & $84.49 c$ & $26.47 a$ & $5.90 \mathrm{~cd}$ & $6.40 \mathrm{ef}$ & $42.80 b c$ \\
\hline $\mathrm{V}_{2} \mathrm{~T}_{4}$ & $79.13 b$ & 12.93de & 10.13ef & $19.90 \mathrm{bcde}$ & 81.40de & $25.40 \mathrm{cde}$ & $5.43 e$ & $6.22 \mathrm{~g}$ & $40.60 \mathrm{bc}$ \\
\hline$V_{3} T_{1}$ & 74.00cde & $13.93 b$ & $13.07 \mathrm{~b}$ & $18.43 \mathrm{~g}$ & $80.67 e$ & $24.00 \mathrm{~h}$ & 6.03ab & $5.90 \mathrm{~h}$ & $30.45 \mathrm{~h}$ \\
\hline$V_{3} T_{2}$ & $79.00 \mathrm{~b}$ & $14.07 \mathrm{ab}$ & $13.80 \mathrm{a}$ & $20.60 \mathrm{abc}$ & 89.33ab & $24.60 \mathrm{~g}$ & 6.00abc & $6.55 \mathrm{~cd}$ & $35.68 d$ \\
\hline$V_{3} T_{3}$ & 79.27 b & $14.69 a$ & $13.93 a$ & $20.81 \mathrm{ab}$ & $90.11 \mathrm{a}$ & 26.17ab & 6.10a & $7.10 a$ & $51.27 a$ \\
\hline$V_{3} T_{4}$ & $76.93 \mathrm{bcd}$ & $14.03 b$ & $13.50 \mathrm{ab}$ & $19.76 \mathrm{cdef}$ & $87.33 b$ & $25.10 \mathrm{def}$ & $5.95 \mathrm{bcd}$ & $6.65 b c$ & 42.79 bc \\
\hline $\mathrm{V}_{4} \mathrm{~T}_{1}$ & 83.87 a & $11.97 \mathrm{fg}$ & $10.77 \mathrm{de}$ & $20.57 a b c$ & $80.12 \mathrm{e}$ & $24.10 \mathrm{~h}$ & $5.95 \mathrm{bcd}$ & $6.00 \mathrm{~h}$ & $32.95 \mathrm{e}$ \\
\hline $\mathrm{V}_{4} \mathrm{~T}_{2}$ & $79.40 \mathrm{~b}$ & $13.10 d$ & $12.33 c$ & $20.75 a b$ & 88.97ab & $24.73 \mathrm{fg}$ & 6.00abc & $6.30 \mathrm{fg}$ & $39.67 \mathrm{~cd}$ \\
\hline$V_{4} T_{3}$ & $80.00 \mathrm{ab}$ & $13.77 \mathrm{bc}$ & $12.93 \mathrm{bc}$ & 20.39abcd & $90.79 a$ & $25.30 \mathrm{de}$ & $5.850 \mathrm{~d}$ & $6.70 \mathrm{~b}$ & 50.10ab \\
\hline $\mathrm{V}_{4} \mathrm{~T}_{4}$ & $76.97 \mathrm{bcd}$ & $12.03 \mathrm{fg}$ & $11.10 d$ & $20.69 a b c$ & $83.59 \mathrm{~cd}$ & $24.80 f g$ & $5.98 a$ & 6.45de & $45.23 b$ \\
\hline $\begin{array}{c}\text { Level of } \\
\text { significance }\end{array}$ & $* *$ & $* *$ & $* *$ & $* *$ & $* *$ & $* *$ & $* *$ & $* *$ & $* *$ \\
\hline CV (\%) & 3.47 & 2.81 & 4.30 & 3.33 & 1.74 & 1.37 & 1.23 & 1.38 & 4.65 \\
\hline
\end{tabular}

In a column, figures with same letters or without letters do not differ significantly whereas figures with dissimilar letter differ significantly as per DMRT; NS=Non-significant; ${ }^{* *}=$ Significant at $1 \%$ level of probability; $\mathrm{V}_{1}=\mathrm{BRRI}$ dhan $28, \mathrm{~V}_{2}=\mathrm{BRRI}$ dhan29, $\mathrm{V}_{3}=$ Binadhan-8, $\mathrm{V}_{4}=$ Binadhan-10; $\mathrm{T}_{1}=$ Control (no manure \& fertilizer), $\mathrm{T}_{2}=$ Recommended dose of inorganic fertilizer; $\mathrm{T}_{3}=$ Bio-slurry @ $5 \mathrm{t} / \mathrm{ha}+$ inorganic fertilizer, $\mathrm{T}_{4}=$ Farmers' practice (average 15 farmers). 


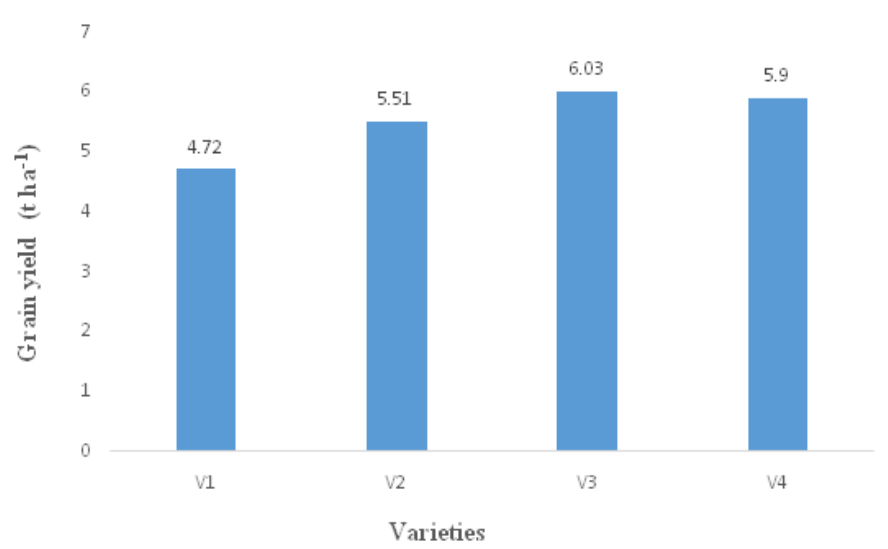

Figure 1. Effect of varieties on grain yield in boro rice.

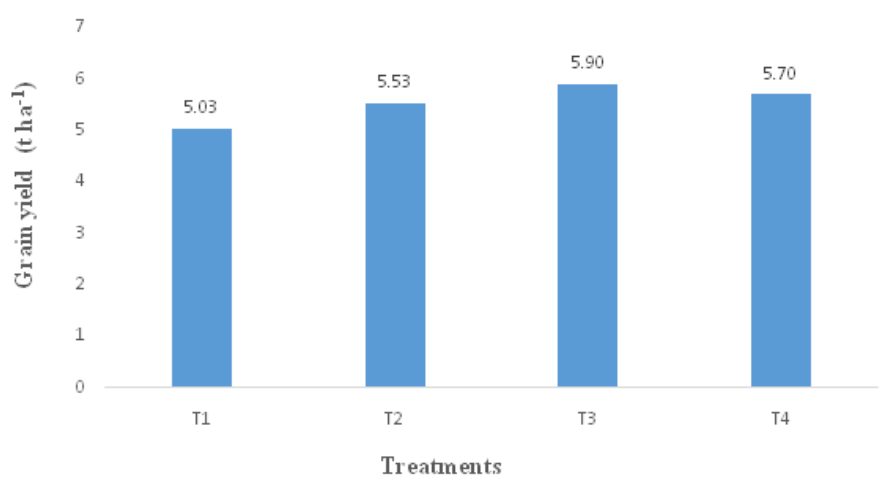

Figure 3. Effect of fertilizer management on grain yield in boro rice.

\section{RESULTS AND DISCUSSION}

\section{Effect on plant characters}

\section{Plant height}

The plant height was non-significant for the variety and fertilizer management (Tables 1 and 2). However the tallest plant height $\left(80.06 \mathrm{~cm}\right.$ ) was observed in $\mathrm{V}_{4}$ (Binadhan-10) and the shortest plant height $(74.17 \mathrm{~cm})$ was observed in BRRI dhan28. In case of fertilizer management, the tallest plant height (79.15 $\mathrm{cm}$ ) was observed in $\mathrm{T}_{3}$ (bio-slurry @ 5t/ha + inorganic fertilizer) and the lowest was found on $\mathrm{T}_{1}$ (control). Variation in plant height might be due to the differences in their genetic makeup. The genetic makeup of the cultivar was responsible for the variation in plant height. This result is in agreement with Hossain and Alam (1999).

\section{Total tillers plant ${ }^{-1}$}

The total tillers plant ${ }^{-1}$ was significantly influenced by the variety and fertilizer management (Tables 1 and 2). Highest tiller (14.16) was found on $V_{3}$ (Binadhan-8) and lowest tiller (12.09) was found on $V_{1}$ (BRRI dhan28). The variation in total number of tillers plant ${ }^{-1}$ may be due to individual tillering habit of the varieties. Variable effect of variety on total number of tillers plant ${ }^{-1}$ was also reported by Hussain (1989) who noticed that total number of tillers plant ${ }^{-1}$ differed among the varieties. In respect of fertilizer management, highest tiller in plant (13.76) was found on $T_{3}$ (bio-slurry @ 5 t/ha + inorganic fertilizer) and lowest

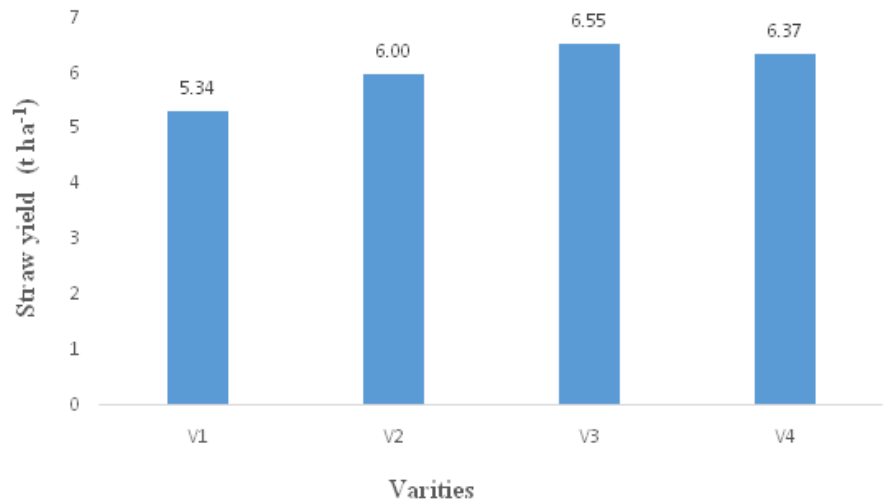

Figure 2. Effect of varieties on straw yield in boro rice; $V_{1}=B R R I$ dhan $28, V_{2}$ $=$ BRRI dhan29, $V_{3}=$ Binadhan $-8, V_{4}=$ Binadhan -10 .

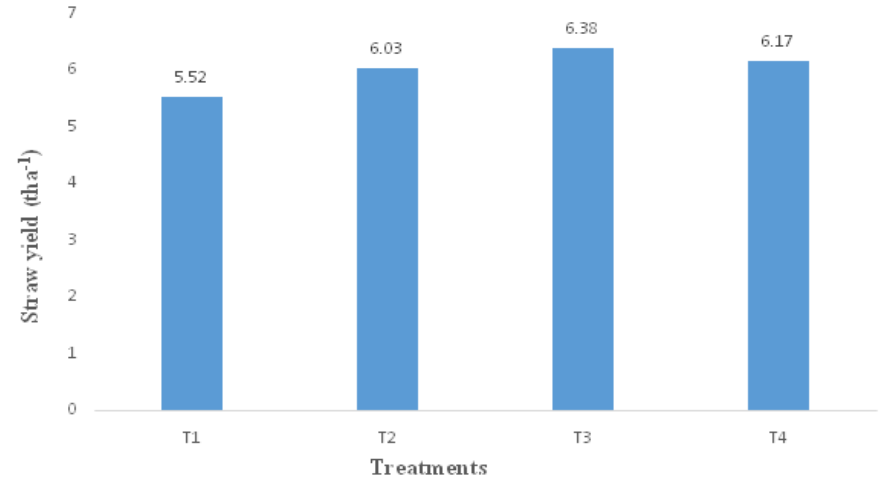

Figure 4. Effect of fertilizer management on straw yield in boro rice; $T_{1}=$ Control (no manure \& fertilizer), $T_{2}=$ Recommended dose of inorganic fertilizer, $T_{3}=$ Bio-slurry @ $5 \mathrm{t} / \mathrm{ha}+$ inorganic fertilizer, $T_{4}=$ Farmers' practice (average 15 farmers).

tiller (12.18) was found on $T_{1}$ (control). Pandey et al. (1991) and Thakur (1993) also reported the similar results from their studies. Number of total tillers plant ${ }^{-1}$ was significantly influenced a by the interaction effect of variety and fertilizer application (Table 3). The Highest number of total tillers plant ${ }^{-1}$ (14.69) was produced by interaction between $\mathrm{V}_{3} \times \mathrm{T}_{3}$ (Binadhan- 8 with bio-slurry @ $5 \mathrm{t} / \mathrm{ha}+$ inorganic fertilizer) and lowest tillers plant ${ }^{1}$ (10.87) was produced by interaction between $\mathrm{V}_{1} \times \mathrm{T}_{1}$ (BRRI dhan28 with control).

\section{Effective tillers plant ${ }^{-1}$}

The effective tillers plant ${ }^{-1}$ was significantly influenced by variety (Table 1). Highest no of effective tillers in plant was found on $V_{3}$ (Binadhan-8) and lowest no of effective tillers (8.87) was found on $\mathrm{V}_{1}$ (BRRI dhan28). The probable reason of difference among the varieties in producing the number of effective tillers plant ${ }^{-1}$ is the genetic makeup of the varieties. The present result is in agreement with that of Chowdhury et al. (1993) who states that ear bearing tillers hill ${ }^{-1}$ varied with varieties.

The effective tillers plant ${ }^{-1}$ was significantly influenced by different level of fertilizer application (Table 2). Highest no of effective tiller (12.03) in plant was found on $\mathrm{T}_{3}$ (bio-slurry @ $5 \mathrm{t}$ / ha + inorganic fertilizer) and lowest tiller (10.14) was found on $\mathrm{T}_{1}$ (control). Number of effective tillers hill ${ }^{-1}$ was significantly influenced by the interaction effect of variety and fertilizer management (Table 3). The highest number of effective tiller 
plant $^{-1}$ (13.93) was produced by interaction between $V_{3} \times T_{3}$ (Binadhan-8 with bio-slurry @ 5 t/ha + inorganic fertilizer) and lowest tillers plant $^{1}$ (7.80) was produced by interaction between $\mathrm{V}_{1} \times \mathrm{T}_{1}$ (BRRI dhan28 with control). The results corroborated with findings of Jeptoo et al. (2013) and Li et al. (2014).

\section{Panicle length}

The panicle length of the plant was not significant for variety (Table 1). However the longest panicle $(20.60 \mathrm{~cm})$ was found on $\mathrm{V}_{4}$ (Binadhan-10) and shortest $(19.56 \mathrm{~cm})$ was for $\mathrm{V}_{2}$ (BRRI dhan29). The panicle length of the plant was found significant for fertilizer management (Table 2). Longest panicle (20.60) was found on $\mathrm{T}_{3}$ (bio-slurry @ $5 \mathrm{t}$ /ha + inorganic fertilizer) and shortest panicle (19.08) found from $\mathrm{T}_{1}$ (control). Awan et al. (1984) reported the almost similar effect of different nitrogen applications on rice grain yield while Rafey et al. (1989) also observed similar effect of $\mathrm{N}$ of growth, yield and nutrient uptake of upland rice. Panicle length of the plant was significantly influenced by the interaction effect of variety and fertilizer management (Table 3). The longest panicle $(21.28 \mathrm{~cm})$ was found from interaction between $\mathrm{V}_{1} \times \mathrm{T}_{3}$ (BRRI dhan28 with bio-slurry @ $5 \mathrm{t} / \mathrm{ha}+$ inorganic fertilizer) and shortest panicle $(18.40 \mathrm{~cm})$ was produced by interaction between $\mathrm{V}_{1} \times \mathrm{T}_{1}$ (BRRI dhan28 with control).

\section{Grains panicle $^{-1}$}

The grains panicle ${ }^{-1}$ was found significant for the variety (Table 1). Highest grains panicle $e^{-1}$ (86.86) was found on $V_{3}$ (Binadhan-8) and lowest grains panicle ${ }^{-1}(73.54)$ was found on $V_{1}$ (BRRI dhan28). Varietals differences regarding the number of grains panicle ${ }^{-1}$ might be due to their difference in genetic constituents. BRRI (1994) reported that the number of grains panicle ${ }^{-1}$ influenced significantly due to variety. The grains panicle ${ }^{-1}$ influenced by fertilizer management (Table 2 ) and found significant. Highest grains panicle ${ }^{-1}$ (85.32) was found on $\mathrm{T}_{3}$ (bio-slurry @ 5 t/ha + inorganic fertilizer) and lowest grains panicle ${ }^{-1}(77.77)$ found from $T_{1}$ (control). The grains panicle ${ }^{-1}$ of the plant was significantly influenced by the interaction effect of variety and fertilizer management (Table 3). The Highest grains panicle ${ }^{-1}$ (90.11) was produced by interaction between $V_{4} \times T_{3}$ (Binadhan10 with bio-slurry @ 5 t/ha + inorganic fertilizer) and lowest grains panicle ${ }^{-1}(70.84)$ was produced by interaction between $\mathrm{V}_{1} \times \mathrm{T}_{1}$ (BRRI dhan 28 with control).

\section{0 'grains weight}

The 1000-grains weight was found significant for variety (Table 1). Highest grains weight (25.85 g) was found on $V_{2}$ (BRRI dhan29) and lowest grains weight (24.74 g) was found on $V_{4}$ (Binadhan-10). The variation in weight of 1000 grain might be due to different sizes of grain that was partly controlled by genetic make up of the studied varieties. Chowdhury et al. (1993) also expressed almost similar views on the effect of variety and number of seedlings hill $^{-1}$ on the yield and its components of boro rice. The 1000-grains weight was found significant for fertilizer management (Table 2). Highest grains weight
(25.94 g) was found on $\mathrm{T}_{3}$ (bio-slurry @ $5 \mathrm{t} / \mathrm{ha}+$ inorganic fertilizer) and lowest grains weight $(24.68 \mathrm{~g})$ found from $\mathrm{T}_{1}$ (control). The results were in consistent with the report of Chandrasharan and Salam (1995). The weight of 1000-grains of the plant was significantly influenced by the interaction effect of variety and fertilizer management (Table 3). The highest grains weight (26.47 g) was produced by interaction between $\mathrm{V}_{2} \times \mathrm{T}_{3}$ (BRRI dhan29 with bio-slurry @ 5 t/ha + inorganic fertilizer) and lowest grains weight $(24.00)$ was produced by interaction between $\mathrm{V}_{3} \times \mathrm{T}_{1}$ (Binadhan-8 with control).

\section{Grain yield}

The grain yield was found significant for the variety (Figure 1). The grain yield ranges from 4.72 to $6.03 \mathrm{t} \mathrm{ha}^{-1}$. Figure 1 indicates that highest grain yield $\left(6.03 \mathrm{t} \mathrm{ha}^{-1}\right)$ was found in $\mathrm{V}_{3}$ (Binadhan-8) and lowest grain yield $\left(4.72 \mathrm{t} \mathrm{ha}^{-1}\right.$ ) was found on $\mathrm{V}_{1}$ (BRRI dhan28). The grain yield weight influenced by fertilizer management (Figure 3). Highest grain yield $\left(5.90 \mathrm{tha}^{-1}\right)$ was found on $\mathrm{T}_{3}$ (bio-slurry @ $5 \mathrm{t} / \mathrm{ha}+$ inorganic fertilizer) and lowest grain yield (5.03 $\mathrm{t} \mathrm{ha}^{-1}$ ) found from $\mathrm{T}_{1}$ (control). The grain yield of the plant was significantly influenced by the interaction effect of variety and fertilizer management (Table 3 ). The highest grain yield $\left(6.10 \mathrm{t} \mathrm{ha}^{-1}\right.$ ) was produced by both interaction between $\mathrm{V}_{3} \times \mathrm{T}_{3}$ (Binadhan-8 with bio-slurry @ 5t/ha + inorganic fertilizer). The lowest grain yield (4.68 $\mathrm{t} \mathrm{ha}^{1}$ ) was produced by interaction of $\mathrm{V}_{1} \times \mathrm{T}_{4}$ (BRRI dhan28 with Farmers' practice). These results are in accordance with Akhtar (2011).

\section{Straw yield}

The straw yield was found significant for the variety (Figure 2). The straw yield ranges from 5.34 to $6.55 \mathrm{t} \mathrm{ha}^{-1}$. Figure 2 indicates that highest straw yield $\left(6.55 \mathrm{t} \mathrm{ha}^{-1}\right)$ was found on $\mathrm{V}_{3}$ (Binadhan-8) and lowest straw yield (5.34 $\mathrm{t} \mathrm{ha}^{-1}$ ) was found on $\mathrm{V}_{1}$ (BRRI dhan28). These results are consistent with those obtained by Chowdhury et al. (1993) who reported differences in straw yield among varieties. The straw yield weight influenced by fertilizer management (Figure 4). Highest straw yield (6.38 $\mathrm{t} \mathrm{ha}^{-1}$ ) was found on $\mathrm{T}_{3}$ (bio-slurry @ $5 \mathrm{t} / \mathrm{ha}+$ inorganic $\mathrm{f}$ ertilizer) and lowest straw yield $\left(5.52 \mathrm{t} \mathrm{ha}^{-1}\right)$ found fromT 1 (control). Usha et al. (2001) also reported the effects of low fertilizers management on different rice varieties. The straw yield of the plant was significantly influenced by the interaction effect of variety and fertilizer management (Table 3).The Highest straw yield (7.10 $\mathrm{t} \mathrm{ha}^{1}$ ) was produced by interaction between $\mathrm{V}_{3} \times \mathrm{T}_{3}$ (Binadhan-8 with bio-slurry @ 5 t/ha + inorganic fertilizer) and lowest straw yield $\left(4.75 \mathrm{t} \mathrm{ha}^{1}\right.$ ) was produced by interaction between $\mathrm{V}_{1} \times \mathrm{T}_{1}$ (BRRI dhan28 with control). Similar finding were also reported by Chaplot and Sumeriya (2013)

\section{Harvest index}

The harvest index was found significant for variety (Table 1). Highest harvest index (47.25\%) was found on $V_{3}$ (Binadhan-8) and lowest (24.35\%) was recorded on $V_{1}$ (BRRIdhan28). An irregular trend of increasing harvest index with the change of variety was observed in the result (Table 1). Application of 
different level of fertilizer management exerted a significant influence on the harvest index (Table 2). The highest index (46.75\%) was found on $\mathrm{T}_{3}$ (bio-slurry @ 5t/ha + inorganic fertilizer) and lowest (24.38\%) found from $T_{1}$ (control). The harvest index of the plant was significantly influenced by the interaction effect of variety and fertilizer management (Table 3). The highest index (51.27\%) was produced by interaction between $V_{4} \times T_{3}$ (Binadhan-10 with bio-slurry @ $5 \mathrm{t} / \mathrm{ha}+$ inorganic fertilizer) and lowest index (29.40\%) was produced by interaction between $\mathrm{V}_{1} \times \mathrm{T}_{1}$ (BRRI dhan28 with control).

\section{Conclusion}

Results of the experiment showed that variety had significant effect on yield contributing parameters and yield. The highest values of most of the characters were found on Binadhan-8. Results of the experiment also demonstrated that fertilizer management had significant effect on yield contributing parameters and yield. The highest value of all characters were observed with the application of $\mathrm{T}_{3}$ (Bio-slurry @ 5t/ha + inorganic fertilizer) followed by $\mathrm{T}_{2}$ (Recommended dose of inorganic fertilizer), $\mathrm{T}_{4}$ (farmers practice) and all cases the lowest one was observed when the land was fertilized with $\mathrm{T}_{1}$ (control). Interaction effects of variety and fertilizer management were significant for most of the yield contributing characters and yield. The highest grain yield $\left(6.10 \mathrm{t} \mathrm{ha}^{-1}\right)$, the highest straw yield (7.10 $\mathrm{t} \mathrm{ha}{ }^{-1}$ ), were found from the combination of $\mathrm{V}_{3} \times \mathrm{T}_{3}$ (Binadhan-8 with bio-slurry @ $5 \mathrm{t} / \mathrm{ha}+$ inorganic fertilizer). The lowest grain yield $\left(4.76 \mathrm{tha}^{-1}\right)$ and straw yield $\left(4.75 \mathrm{t} \mathrm{ha}^{-1}\right)$ were found from the interaction of $\mathrm{V}_{1} \times \mathrm{T}_{1}$ (BRRI dhan 28 with control). Based on the present study it can be suggested that the farmers' can grow boro rice cv. Binadhan-8 with bio-slurry @ 5 t/ha + inorganic fertilizer in boro season for obtaining maximum grain yield.

Open Access: This is open access article distributed under the terms of the Creative Commons Attribution License, which permits unrestricted use, distribution, and reproduction in any medium, provided the original author(s) and the source are credited.

\section{REFERENCES}

Akhtar, M. J. (2011). Bioslurry as nutrient source for sustainable agriculture. First year report on evalution of bioslurry as nutrient source for sustainable agriculture.

Asadul, M., Haque, M., Jahiruddin, M., Rahman, M. and Saleque, M.A. (2015). Usability of bioslurry to improve system productivity and economic return under potato-rice cropping system. Research in Agriculture, Livestock and Fisheries, 2 (1): 27-33, http://dx.doi.org/10.3329/ralf.v2i1.23026

Awan, I.U., Ahmed, H.K. and Gandapur, S.U.D. (1984). Effect of different nitrogen applications on rice grain yield. International Rice Research News, 9(6): 26-31.

BARC, Bangladesh Agricultural Research Council (2005). Fertilizer
Recommendation Guide, Farmgate, Dhaka-1215, pp. 260.

BRRI, Bangladesh Rice Research Institute (1994). Annual Report for 1993. Bangladesh Rice Research Institute, Joydebpur, Gazipur, Bangladesh, pp. 8-9.

Chandrasharan, P. and Salam, M.A. (1995). Nitrogen nutrition of 'Rohini' a short duration rice variety. Agricultural Research Journal of Kerala, 23(2): 200-202.

Chaplot, P.C. and Sumeriya, H.K. (2013). Yield and economics of late sown wheat as influenced by balanced fertilization, organic manures and bioregulator. Advance Journal of Advance Research and Crop Improvement, 4:47-50, http:// www.researchjournal.co.in/upload/assignments/4_4750.pdf

Chowdhury, M.J.U., Sarkar, A.U., Sarkar, M.A.R. and Kashem, M.A. (1993). Effect of variety and number of seedlings hill ${ }^{-1}$ on the yield and its components on boro rice. Bangladesh Journal of Agricultural Science, 20(2): 311-316.

Cuong, T.X., Ullah, H., Datta, A. and Hanh, T.C. (2017). Effects of silicon-based fertilizer on growth, yield and nutrient uptake of rice in tropical zone of Vietnam. Rice Science, 24(5):283290, https://doi.org/10.1016/j.rsci.2017.06.002

Dada, O., Togun, A., Adediran, J. and Nwilene, F. (2014) Growth, Nutrient Uptake Efficiency and Yield of Upland Rice as Influenced by Two Compost Types in Tropical RainforestDerived Savannah Transition Zone. Agricultural Sciences, 5: 383-393, https://doi.org/10.4236/as.2014.55040

FAO and UNDP. (1988). Land Resources Appraisal of Bangladesh for Agricultural Development Report 2: Agroecological Regions of Bangladesh. Food and Agricultural Organization, Rome, Italy.

Garg, R.N., Pathak, K., Tomar, H. and Das, D.K. (2005). Use of flyash and biogas slurry for improving wheat yield and physical properties of soil. Environmental Monitoring Assessment, 107:1-9.

Gomez, M.A. and Gomez, A.A. (1984). Statistical Procedures for Agricultural Research. John Willey and Sons. New York, Chichester, Brisbane, Toronto, 207-215.

Gupta, M.K. (2007). Hand book of organic farming and bofertilizers (1st Edn.) ABD publishers, Jaipur, India.

Hossain, S.M.A. and Alam, A.B.M.M. (1999). Productivity of cropping patterns of participating farmers. In fact searching and intervention in two FSRDP sites, activities 1989-90: Farming Systems Research and Development Programme, BAU, Mymensingh.

Hussain, M.D. (1989). Autoecology of E. crus-galli and its control in direct seeded boro rice. MS Thesis, Department of Agronomy, Bangladesh Agricultural University, Mymensingh.

Islam, M.A., Islam, M.F., Rahman, J., Sarkar, M.A.R., Rahman, M.R. (2017). Effect of variety and spacing of transplanting on the yield and yield components of boro rice. International Journal of Applied Research, 3(1): 7-12, http://intjar.com/wpcontent/uploads/2017/02/IJAR-2017-0055-7-12.pdf

Jeptoo, A., Aguyoh, J.N. and Saidi, M. (2013). Improving carrot yield and quality through the use of bio-slurry manure. Sustainable Agriculture Research, 2(1): 164-172, 
http://dx.doi.org/10.5539/sar.v2n1p164

Khan, S.A., Malav, L.C., Kumar, S., Malav, M.K., and Gupta, N. (2015). Resource utilization of biogas slurry for better yield and nutritional quality of baby corn. Advances in Environmental and Agricultural Science, 382-394.

Li Y., Sheng K., Peng S., Meng, Z. and Dong, Z. (2014). Effects of biogas slurry on wheat yield and the physical and chemical properties of soil. Chinese Agricultural Science Bulletin, 181186.

Mondal, (2000). BARI Project report, Bangladesh Agricultural Research Institute, Bio-slurry management and its effect on soil fertilizer and crop production, pp. 5.

Pandey, S.K., Rajkumar, R.S. and Singh, B.B. (1991). Effect of different doses of nitrogen on dwarf and tall varieties of rice (Oryza sativa). Indian Journal of Agricultural Science, 61
(2): 135-138.

Rafey, A., Khan, P.A. and Srivastava, V.C. (1989). Effect of $N$ of growth, yield and nutrient uptake of upland rice. Indian Journal of Agronomy, 34(1): 133-135.

Shankarappa, T.H. Gurumurthy, S.B., Patil, S.V. and Lokesh, M.S. (2012). Influence of phosphorus enriched biogas spent slurry (BSS) on growth and yield of sunflower (Helianthus annuus). Journal of Plant Science, 7: 253-258.

Thakur, R.B. (1993). Performance of summer rice (Oryza sativa L.) to varying levels of nitrogen. Indian Journal of Agronomy, 38(2): 187-190.

Usha, K.E., Mecraleedharan, V.K., Kuriakose, T.F. and Prasannakumri, K.T. (2001). Rice varieties studies for low fertilizer management. Journal of Tropical Agriculture, 39(2): 170-171. 